\title{
DESAIN PEMBELAJARAN BAHASA INGGRIS UNTUK PENDIDIKAN ANAK USIA DINI
}

\author{
Ida Vera Sophya
}

Dosen Jurusan Tarbiyah STAIN Kudus

\begin{abstract}
Early Childhood Education is one form of the provision of education that focuses on the foundation of the direction of growth and development. At an early age, children can be taught basics English only and they are taught it by directed playing. Through directed playing, children can learn many things. Instructional design is an integral part of several components of interacting learning, interrelation and interdependence in achieving the learning objectives that have been set. Learning component includes students, teachers, curriculum, teaching materials, instructional media, learning resources, learning processes, facilities, environment and learning objectives. These components should be designed in accordance with the developing learning program.
\end{abstract}

Keywords: Early Childhood Education, English learning design

\section{A. PENDAHULUAN}

Pendidikan mencakup usaha sadar untuk menciptakan suatu lingkungan yang memungkinkan perkembangan yang optimal dari potensi yang dibawa lahir oleh peserta didik sejak dini. Pendidikan anak usia dini (PAUD) sebagai bagian dari seluruh usaha sadar melaksanakan pembangunan manusia seutuhnya, sejak dekade terakhir telah mengambil tempat yang sentral dalam membangun masyarakat Indonesia.

Anak usia dini adalah sosok individu yang sedang menjalani suatu proses perkembangan dengan pesat dan fundamental bagi kehidupan selanjutnya. Anak usia dini berada pada rentang usia 0-8 tahun. Pada 251 
masa ini proses pertumbuhan dan proses perkembangan dalam berbagai aspek sedang mengalami masa yang cepat dalam rentang perkembangan hidup manusia (Berk, 1992:18). Proses pembelajaran sebagai bentuk perlakuan yang diberikan pada anak harus memperhatikan karakteristik yang dimiliki setiap tahapan perkembangan anak.

Berdasarkan Undang-undang Nomor 20 Tahun 2003 tentang Sistem Pendidikan Nasional berkaitan dengan Pendidikan Anak Usia Dini tertulis pada pasal 28 ayat 1 yang berbunyi "Pendidikan Anak Usia Dini diselenggarakan bagi anak sejak lahir sampai dengan enam tahun dan bukan merupakan prasyarat untuk mengikuti pendidikan dasar". Selanjutnya Bab 1 ayat 14 ditegaskan bahwa Pendidikan Anak Usia Dini adalah suatu upaya pembinaan yang ditujukan kepada anak sejak lahir sampai dengan usia enam tahun yang dilakukan melalui pemberian rangsangan pendidikan untuk membantu pertumbuhan dan perkembangan jasmani dan rohani agar anak memiliki kesiapan dalam memasuki pendidikan lebih lanjut (Depdiknas USPN, 2004:4). Pendidikan AnakUsia Dini merupakan salah satu bentukpenyelenggaraan pendidikan yang menitik beratkan pada peletakan dasar ke arah pertumbuhan dan perkembangan antara lain:

1. Fisik yaitu koordinasi motorik halus dan kasar,

2. Kecerdasan yang terdiri dari daya pikir, daya cipta, kecerdasan emosi, kecerdasan spiritual,

3. Sosio emosional terdiri dari sikap dan perilaku serta beragama, Bahasa dan komunikasi

Tentu saja pertumbuhan dan perkembangan tersebut di atas disesuaikan dengan keunikan dan tahapan-tahapan perkembangan yang dilalui oleh anak usia dini. Oleh karena itu, dalam penyelenggaraan lembaga pendidikan pada anak usia dini harus berbasis pada kebutuhan anak.

Pendidikan bagi anak usia dini adalah pemberian upaya yang menstimulasi, membimbing mengasuh dan memberikan kegiatan pembelajaran yang akan menghasilkan kemampuan dan keterampilan anak. Pendidikan bagi anak usia dini merupakan sebuah pendidikan yang dilakukan pada anak yang baru lahir sampai dengan umur delapan tahun. Pendidikan pada tahap ini memfokuskan pada physical, intelligence/cognitive, emotional, dan social emotional.

Pendidikan pada anak usia dini pada dasarnya meliputi seluruh 252 upaya dan tindakan yang dilakukan oleh guru dan orang tua dalam 
proses perawatan, pengasuhan dan pendidikan pada anak dengan menciptakan aura dan lingkungan dimana anak dapat mengeksplorasi pengalaman yang memberikan kesempatan kepadanya untuk mengetahui dan memahami pengalaman belajar yang diperoleh dari lingkungan, melalui cara mengamati, meniru dan bereksperimen yang berlangsung secara berulang-ulang dan melibatkan seluruh potensi dan kecerdasan anak. Oleh karena anak merupakan pribadi yang unik dan melewati berbagai tahap perkembangan kepribadian, maka lingkungan yang diupayakan oleh pendidik dan orang tua yang dapat memberikan kesempatan pada anak untuk mengeksplorasi berbagai pengalaman dengan berbagai suasana, hendaklah memperhatikan keunikan anakanak dan disesuaikan dengan tahapan perkembangan kepribadian anak.

Pada zaman sekarang ini bahasa Inggris tidak boleh dipandang sebelah mata. Hal ini dikarenakan Bahasa Inggris telah menjadi bahasa internasional yang digunakan hampir di segala bidang kehidupan global. Bahasa Inggris juga telah menjadi bahasa dunia yang mendominasi era komunikasi untuk menghubungkan dan mentransfer ilmu ke seluruh dunia. Hal ini memberikan asumsi bahwa penguasaan bahasa Inggris merupakan kebutuhan yang sangat penting bagi masyarakat modern sekarang ini karena penguasaan terhadap bahasa Inggris memudahkan seseorang untuk memperluas pergaulannya di dunia internasional. Seperti yang dikatakan oleh Fromkin, "English has been called : The Lingua Franca of the worls" (1990:259). tua yang ingin mengajarkan anaknya belajar bahasa Inggris sejak usia dini. Memang tidak gampang untuk mengajarkan bahasa Inggris untuk anak usia dini. Oleh karena itu, seorang guru PAUD harus mempunyai cara yang sangat berbeda dalam pengajarannya jika dibandingkan dengan remaja atau dewasa.

Pada usia dini, anak-anak hanyalah bisa diajarkan bahasa Inggris pada dasar-dasarnya saja dan mereka diajarkan dengan cara yang mereka ketahui yaitu bermain, akan tetapi bukan sekedar bermain. Bermain di sini adalah bermain yang diarahkan. Melalui bermain yang diarahkan, anak-anak tersebut bisa belajar banyak hal. Perlu kita ketahui bahwa pada saat bermain, keadaan otak anak sedang tenang karena dia merasa senang dan ceria. Bila keadaan otak anak dalam keadaan tenang tentu saja ilmu bisa masuk dan tertanam dengan mudah dan baik

Berdasarkan paparan yang dikemukakan di atas, maka rumusan masalah yang dapat diangkat adalah bagaimana desain pembelajaran Bahasa Inggris untuk anak usia dini? 


\section{B. PEMBAHASAN}

Menurut Departemen Pendidikan dan Kebudayaan (2001), bahasa merupakan alat untuk menyatakan pikiran dan perasaan kepada orang lain yang sekaligus juga berfungsi untuk memahami pikiran dan perasaan orang lain. Dengan kata lain bahasa merupakan suatu alat yang digunakan oleh manusia untuk menyatakan suatu keinginan atau perasaan, harapan, permintaan, dan lain-lain kepada orang lain. Bahasa juga memberikan peranan yang bersifat penting dalam perkembangan anak.

Dengan menggunakan bahasa, anak akan tumbuh dan berkembang menjadi manusia dewasa yang dapat bergaul di tengahtengah masyarakat. Periode sensitif terhadap bahasa dalam kehidupan seseorang adalah antara usia 0-8 tahun. Segala macam aspek dalam berbahasa harus diperkenalkan kepada anak sebelum masa sensitif ini berakhir.

Menurut Gagne, Briggs (1979:55) menjelaskan bahwa desain pembelajaran dapat membantu proses belajar seseorang secara bertahap dalam waktu yang panjang. Mereka menyatakan bahwa proses belajar terjadi karena adanya kondisi-kondisi belajar internal dan eksternal. Kondisi internal adalah kemampuan dan kesiapan diri anak. Kondisi eksternal adalah pengaturan lingkungan belajar yang didesain oleh guru. Jadi, persiapan kondisi belajar eksternal ini yang harus didesain dan dilaksanakan oleh guru dalam kegiatan pembelajaran.

Desain pembelajaran merupakan satu kesatuan dari beberapa komponen pembelajaran yang saling berinteraksi, interelasi, dan interdependensi dalam mencapai tujuan pembelajaran yang telah ditetapkan. Komponen pembelajaran meliputi peserta didik, pendidik, kurikulum, bahan ajar, media pembelajaran, sumber belajar, proses pembelajaran, fasilitas, lingkungan, dan tujuan. Komponen-komponen tersebut hendaknya dirancang sesuai dengan program pembelajaran yang dikembangkan. Adapun masing-masing dari komponen tersebut dapat dijabarkan antara lain:

1. Karakteristik Anak Usia Dini

Seorang pendidik anak usia dini sebelum melaksanakan kegiatan pembelajaran terlebih dahulu memperhatikan karakteristik anak-anak yang dididik dan diajar agar program pembelajarannya sesuai dengan perkembangan dimensi anak-anak yang meliputi dimensi kognitif, bahasa, kreativitas, emosional dan sosial. Adapun secara umum karakteristik anak-anak usia dini yang dimaksud meliputi: 
a. Aspek Kognitif

Dari aspek kognitif, Moeslichatoen, (1999) menyatakan bahwa anak usia dini, paling tidak memiliki empat karakteristik yang melekat pada diri mereka. Keempat karakteristik tersebut adalah

b. Mereka telah memiliki kemampuan untuk menginterpretasikan arti /makna

1. Mereka memiliki daya perhatian dan konsentrasi yang terbatas

2. Mereka telah memiliki daya imajinasi

3. Mereka memahami situasi

c. Aspek Afektif

Sedangkan menurut Haliwell (1992) mengatakan bahwa dari aspek aspek afektif, anak usia dini secara teoritis dan empiris memiliki sifat-sifat seperti :

1. Mereka senang menemukan dan menciptakan sesuatu

2. Mereka senang berbicara

3. Mereka senang bermain dan bekerja sendiri

4. Mereka tertarik pada aktivitas yang relevan bagi mereka

d. Aspek Psikomotorik

Dari aspek psiko-motor, Moeslichatoen, (1999); Haliwell, (1992) menyatakan bahwa anak usia dini memiliki kemampuan psiko-motorik tertentu. Kemampuan psikomotorik tersebut meliputi

1. Mereka memiliki keterampilan dalam memakai bahasa secara terbatas namun kreatif

2. Mereka dapat belajar dengan melakukan sesuatu

3. Mereka belajar bahasa Inggris dengan menggunakannya

4. Mereka dapat bekerja sama dengan orang dewasa

5. Mereka akan belajar dengan sangat baik apabila mereka terlibat dalam aktivitas yang relevan dengan diri mereka.

Dengan memperhatikan karakteristik anak-anak tersebut, tujuan pembelajaran bahasa Inggris untuk anak usia dini secara umum dapat ditentukan sebagai berikut: 1) membuat anak merasa berkompeten dan percaya diri dalam belajar bahasa Inggris, 2) menyediakan lingkungan pembelajaran yang aman, bersifat menghibur dan rekreatif serta mendidik, 3) menciptakan pembelajar bahasa Inggris untuk dalam waktu jangka panjang. 
2. Karakteristik Pendidik

Hakikat pembelajaran bahasa Inggris pada prinsipnya adalah suatu proses pemerolehan bahasa yang dilakukan secara sengaja dan bertujuan dalam ruang lingkup proses pembelajaran di kelas atau di luar kelas dengan mengikuti kaidah-kaidah suatu pembelajaran. Pembelajaran bahasa Inggris bagi anak usia dini adalah suatu bidang yang dinamis sehingga bisa dipastikan akan senantiasa mengalami perubahan-perubahan. Namun demikian, tugas para pendidik bagi anak usia dini tetaplah sama yakni membantu perkembangan, pemahaman dan penggunaan bahasa mereka melalui perencanaan, pembimbingan dan penyediaan sarana penunjang yang cukup dan memadai.

Profil guru bahasa Inggris untuk anak usia dini menjadi sangat penting. Suyanto (2007) mengatakan bahwa seorang guru bahasa Inggris pada anak usia dini, paling tidak memiliki lima karakteristik. Kelima karakteristik tersebut antara lain yaitu : 1) Mempunyai kemampuan bahasa Inggris yang cukup memadai, 2) memiliki keterampilan mengajar diantaranya melakukan assessment dan pengelolaan kelas, 3) memiliki kualitas guru yang efektif seperti sabar, baik hati, suka humor, kreatif, dan bersemangat tinggi, 4) memiliki profesionalitas guru, dan 5) bersifat terbuka untuk bertanya, belajar, memperbaiki diri, dan mencoba hal-hal baru yang sesuai untuk kebutuhan anak didiknya.

Sedangkan dari segi kompetensi dan penggunaan bahasa Inggris, guru bahasa Inggris untuk anak usia dini harus memiliki kemampuan pengetahuan dan keterampilan bahasa Inggris yang memadai. Hal ini penting, karena penggunaan bahasa ibu atau bahasa pertama berbeda dengan penggunaan bahasa Inggris. Untuk itu, mereka harus memahami secara memadai hal-hal seperti 1) struktur atau tata bahasa Inggris, 2) kosakata dasar yang sesuai dengan kebutuhan anak usia dini, 3) pelafalan atau ucapan yang benar, 4) intonasi dan tekanan yang benar, 5) ejaan, dan 6) kultur budaya bahasa Inggris tersebut.

Untuk itu, para pendidik terutama jika mereka akan memulai memberikan pelajaran bahasa Inggris pada anak usia dini harus memahami hal-hal yang mendasar tentang perkembangan diri anak dan dalam hubungannya dengan proses pembelajaran bahasa Inggris. Maka dari itu mereka didorong untuk dapat mengadakan eksplorasi, merencanakan dan mengimplementasikannya dalam proses pembelajaran bahasa Inggris agar pembelajaran tersebut tepat sesuai dengan tujuan yang diharapkan. 
3. Kurikulum Bahasa Inggris dalam PAUD

Kurikulum adalah suatu perencanaan pengalaman belajar secara tertulis yang merupakan usaha-usaha dan kegiatan sekolah untuk merangsang anak agar dapat belajar secara optimal di dalam maupun di luar sekolah. Anak tidak hanya belajar dari apa yang diberikan di sekolah. Dalam merencanakan suatu kurikulum untuk anak, guru harus memilih tujuan, bagaimana mengorganisasikan isi kurikulum, memilih bentuk pengalaman belajar bagi anak, bagaimana urutan pelajaran diberikan dan kemudian menentukan bagaimana melakukan penilaian terhadap hasil belajar. Selain itu guru selayaknya memiliki wawasan yang luas, tanggap dan kreatif agar anak tidak mudah bosan dengan kegiatan yang dirancang guru. Proses pembelajaran pada anak hendaknya dilakukan dengan tujuan memberikan konsep-konsep dasar yang memiliki kebermaknaan bagi anak melalui pengalaman nyata. Melalui pengalaman nyata akan memungkinkan anak untuk menunjukkan aktivitas dan rasa ingin tahu secara optimal dengan menempatkan guru sebagai pendamping, pembimbing serta fasilitator bagi anak. Proses pendidikan semacam ini dapat menghindari bentuk pembelajaran yang hanya berorientasi pada kehendak guru yang menempatkan anak secara pasif dan guru menjadi sangat dominan dalam pembelajaran.

Sejalan dengan itu, kurikulum menjadi sangat penting untuk dirancang dan dikembangkan. Para ahli dan pakar pendidikan memberikan definisi dan pengertian mengenai kurikulum sangat beragam dan relatif berbeda secara tekstual namun tetap memiliki esensi dan inti yang sama. Perbedaan pengertian tersebut tidak bersifat fundamental tetapi lebih bersifat komplementer karena para ahli memandang dari sudut yang berbeda terhadap objek yang sama.

Berkaitan dengan definisi kurikulum (Ali, 1984) dalam Munir (2008) mengatakan bahwa kurikulum dapat diartikan ke dalam tiga ranah yaitu 1) kurikulum sebagai rencana belajar bagi peserta didik, 2) kurikulum sebagai rencana pembelajaran, dan 3) kurikulum sebagai pengalaman belajar peserta didik. Kurikulum sebagai rencana belajar juga dijelaskan oleh Taba dalam Munir (2008). Dia mengatakan bahwa kurikulum adalah sebagai rencana belajar (curriculum is a plan for learning). Untuk itu, biasanya kurikulum terdiri dari tujuan, materi/isi, strategi pembelajaran dan evaluasi. Dalam konteks bentuk-bentuk belajar yang direncanakan memerlukan penjelasan yang lebih komprehensif. Dan penjelasan tersebut sangat erat kaitannya dengan teori lain yang 
relevan seperti psikologi, psikologi belajar anak, dan sebagainya.

Kemudian, Mulyasa (2009) menjelaskan bahwa kurikulum sebagai rencana pembelajaran di lembaga pendidikan baik formal maupun non formal, akademik maupun profesional mencakup sejumlah mata pelajaran yang harus ditempuh dan dipelajari serta dikuasai peserta didik pada jenjang dan satuan pendidikan tertentu. Ini bermakna bahwa proses pendidikan di lembaga pendidikan yang termasuk dalam kurikulum hanya mata pelajaran yang harus dipelajari peserta didik sedangkan proses kegiatan belajar mengajar yang terjadi tidak termasuk ke dalam kurikulum.

Dalam konteks kurikulum sebagai pengalaman belajar, para ahli memandang bahwa kurikulum bukan hanya rencana pembelajaran saja, melainkan juga sebagai suatu pengalaman belajar yang nyata dan aktual yang terjadi dalam proses pendidikan di sekolah.

Namun dalam konteks Indonesia, secara nasional pengertian kurikulum dituangkan dalam Undang-Undang No 12 tahun 2003 tentang Sistem Pendidikan Nasional dan dituangkan dalam Peraturan Pemerintah no 19 tahun 2005 yang merumuskan bahwa:

Kurikulum adalah seperangkat rencana dan pengaturan mengenai tujuan, materi/isi atau bahan pelajaran serta metode cara yang digunakan sebagai pedoman penyelenggaraan kegiatan pembelajaran untuk mencapai tujuan pendidikan.

Merujuk kepada pengertian kurikulum yang tertuang dalam Undang-Undang no 12 tahun 2003, kurikulum yang dimaksud lebih menekankan pada kerangka kerja/rancangan dalam membantu berkembangnya kemampuan-kemampuan peserta didik melalui proses pembelajaran. Dalam kerangka kerja tersebut, kurikulum memuat informasi tentang 1) Apa yang harus dipelajari peserta didik (subjek), 2) Apa yang harus peserta didik ketahui dan mampu lakukan (kompetensi), 3) Berapa lama mereka dapat belajar (jam belajar/minggu) dan 4) Bagaimana cara peserta didik belajar ( tatap muka, tugas terstruktur, dan juga tugas lainnya).

Pelajaran bahasa Inggris pada pendidikan anak usia dini merupakan aspek muatan lokal yang perlu diperhatikan dalam pengembangan kurikulum. Kurikulum PAUD dikembangkan berdasarkan integrated curriculum (kurikulum terintegrasi) dengan pendekatan tematik. Pembelajaran tematik merupakan suatu strategi pembelajaran yang melibatkan beberapa bidang pengembangan untuk 
memberikan pengalaman yang bermakna kepada anak (Kostelnik, 1991:17). Keterpaduan dalam pembelajaran ini dapat dilihat dari aspek proses atau waktu, aspek kurikulum, dan aspek proses belajar mengajar. Pembelajaran tematik

Sesuai dengan perkembangan fisik dan mental anak pada usia empat sampai dengan enam tahun, maka pembelajaran pada tahap ini haruslah mempunyai ciri-ciri sebagai berikut : 1) berpusat pada anak, 2) memberikan pengalaman, 3) pemisahan bidang pengembangan tidak begitu jelas, 4) menyajikan konsep dari berbagai bidang pengembangan dalam suatu proses pembelajaran, 5) bersifat fleksibel atau luwes, 6) hasil pembelajaran dapat berkembang sesuai dengan minat dan kebutuhan anak (Kostelnik, 1991:17-20). Dengan penerapan pembelajaran tematik, maka akan membawa beberapa keuntungan, misalnya:

a. Pengalaman dan kegiatan belajar yang dilakukan relevan dengan tingkat perkembangan dan kebutuhan anak.

b. Menyenangkan karena bertolak dari minat dan kebutuhan anak Hasil belajar akan bertahan lebih lama karena lebih berkesan dan lebih bermakna

c. Mengembangkan keterampilan berpikir anak dengan permasalahan yang dihadapi

d. Menumbuhkan keterampilan sosial dalam bekerja sama, toleransi, komunikasi, dan tanggap terhadap gagasan orang lain.

Tema digunakan pada pembelajaran anak usia dini adalah untuk membangun pengetahuan pada anak dan mengembangkan seluruh aspek perkembangan anak. Dalam mengembangkan tema, hal yang penting untuk diperhatikan adalah bagaimana membangun pengetahuan secara sistematik dan holistik. Tema dapat dikembangkan secara fleksibel sesuai dengan kebutuhan perkembangan anak agar tidak menimbulkan kebosanan. Adapun prinsip pemilihan tema dalam pengenalan bahasa Inggris didasari pada:

a. Tema-tema yang bersifat dasar dan selalu dapat dikembangkan, seperti: parts of house, family, school,

b. Tema yang dihubungkan dengan suatu peristiwa/kejadian, seperti : mountain, flood, museum

c. Tema yang dihubungkan dengan minat anak, seperti : animal, sun

d. Tema yang dihubungkan dengan hari-hari besar atau spesial 
Dalam mengembangkan tema, prinsip yang perlu diperhatikan antara lain : 1) menyediakan kesempatan pada anak untuk terlibat langsung dengan objek yang sesungguhnya, 2) menciptakan kegiatan yang melibatkan seluruh indera anak, 3) membangun kegiatan dari minat anak, 4) membantu anak membangun pengetahuan baru, 5) memberikan kegiatan dan rutinitas yang ditujukan untuk mengembangkan seluruh aspek perkembangan, 6) mengakomodasi kebutuhan anak akan kebutuhannya untuk kegiatan dan gerak fisik, interaksi sosial, kemandirian, konsep diri yang positif, 7) memberikan kesempatan dalam menggunakan permainan untuk menerjemahkan dari pengalaman menjadi pemahaman, 8) menghargai perbedaan individu, latar belakang, pengalaman di rumah yang dapat dibawa anak ke kelas, 9) menemukan jalan untuk melibatkan anggota keluarga dari anak. Tema- tema tersebut diajarkan tidak langsung terfokus pada penggunaan bahasa Inggris melainkan diambilkan kata dasar yang sesuai dengan tema dan kata yang dipahami oleh siswa. Adapun hal yang penting yang perlu diajarkan menurut Mubarok yang ada dalam kurikulum bahasa Inggris pada anak usia dini adalah membahas tentang :

- Vocabulary (kosakata)

- English Songs (bernyanyi lagu bahasa Inggris)

- Short Expression (ungkapan sederhana)

- Phonics (bunyi huruf)

4. Bahan Ajar Pembelajaran Bahasa Inggris di PAUD

Berkaitan dengan substansi materi bahasa Inggris, Ashworth dan Wakefield, (2005) mengatakan bahwa ada dua domain dalam hal ini yaitu aspek tentang bahasa dan aspek tentang konsep. Dari ruang lingkup kebahasaan, pembelajaran bahasa Inggris untuk anak usia dini meliputi keterampilan mendengar, berbicara, membaca dan menulis serta komponen kosakata, pelafalan dan struktur bahasa. Semua ini harus disesuaikan dengan kemampuan anak yang diajar. Sejalan dengan itu, Suyanto (2007) menambahkan bahwa substansi kegiatan belajar bahasa Inggris mencakup kompetensi dan keterampilan berbahasa seperti menyimak (listening), berbicara (speaking), membaca (reading), dan menulis (writing). Keterampilan tersebut diajarkan secara integratif dan terpadu dengan apa yang terjadi dalam kehidupan sehari-hari.

Adapun konsep-konsep yang perlu dikuasai anak-anak dalam berbahasa adalah 1) identifikasi (mengenal orang/benda yang ada di sekitar anak-anak), 2) klasifikasi (pengelompokan, misalnya warna, 
bentuk, ukuran, jumlah, fungsi, jenis, dsb.), 3) spasial (ruang atau posisi orang/benda), 4) temporal (waktu), 5) emosional (perasaan), 6) familial (keluarga), 7) ordering (menyusun), dan 8) ekuivalensi (perbandingan)

Masalah lain yang juga mendapat perhatian serius dalam proses pembelajaran bahasa Inggris pada anak usia dini adalah metode/ cara/strategi yang diterapkan oleh guru. Metode/cara/strategi yang diterapkan oleh guru dalam proses pembelajaran bahasa Inggris tidak lepas dari dua asumsi utama yaitu karakteristik pembelajaran bahasa dan karakteristik anak usia dini. Kedua hal tersebut harus menjadi pertimbangan utama dalam proses pembelajaran bahasa Inggris yang dimaksud.

Dalam pembelajaran bahasa Inggris banyak metode dan teknik yang dapat digunakan, diantaranya melalui story telling (bercerita), role play (bermain peran), Art and crafts (seni dan kerajinan tangan), games (permainan), show and tell, music and movement (gerak dan lagu) dimana termasuk di dalamnya singing (nyanyian) dan Chants and Rhyemes (Nyanyian pendek dan sajak), dan sebagainya. Dalam penggunaan metode dan teknik yang hendak digunakan sebaiknya dipilih dan disesuaikan dengan kemampuan yang ingin dicapai.

Secara alamiah, dalam belajar bahasa Inggris, misalnya, 1) secara alami, sama dengan cara mereka belajar bahasa ibu, 2) anakanak perlu dimotivasi dan di stimulus, 3) kegiatan yang bersifat mendengar dan mengulang-ulang, 4) kegiatan dengan menirukan guru, 5) kegiatan dengan berinteraksi dengan orang lain, dan kegiatan yang bersifat menerjemahkan baik dari bahasa ibu ke bahasa Inggris maupun sebaliknya (Moon, 2000). Pada prinsipnya bahan-bahan ajar yang di pandang cocok bagi anak PAUD adalah sederhana, konkret, sesuai dengan dunia kehidupan anak, terkait dengan situasi pengalaman langsung, atraktif dan berwarna, mengundang rasa ingin tahu anak, bermanfaat dan terkait dengan kegiatan-kegiatan bermain anak.

5. Media Pembelajaran

Kata media berasal dari bahasa latin yaitu jamak dari kata medium yang secara harfiah berarti perantara. Media adalah perantara atau pengantar pesan dari pengirim ke penerima pesan (Sadiman, 2002:6). Media merupakan perantara sumber-sumber berbagai elemenelemen yang penting yang ada di dalam lingkungan anak-anak yang dapat merangsang anak-anak untuk belajar.

Istilah media yang digunakan dalam bidang pembelajaran $26 \mathrm{~T}$ 
disebut media pembelajaran. Dalam proses pembelajaran, alat bantu atau media tidak hanya dapat memperlancar proses komunikasi akan tetapi dapat merangsang anak-anak untuk merespons dengan cepat tentang pesan yang disampaikan.

Proses pembelajaran merupakan proses komunikasi antara pembelajar (komunikan), pengajar (komunikator) dan bahan ajar (pesan). Sebagai tenaga pendidik, guru atau komunikator harus mampu menciptakan kondisi sebaik mungkin agar pesan yang disampaikan dapat diterima dengan baik (efektif) oleh pembelajar (komunikan). Salah satu cara yang efektif adalah dengan media.

Seperti yang dijelaskan sebelumnya, bahwa media merupakan suatu alat dalam menyampaikan materi. Akan tetapi apabila media tersebut tidak dapat menjalankan fungsinya, maka media tersebut tidak dapat menjalankan fungsinya, maka media tersebut tidak efektif dan tidak dapat menyampaikan isi pesan kepada anak. Oleh karena itu, media perlu dirancang dengan baik dan benar akan dapat merangsang komunikasi anak dengan sumber media tersebut.

Awalnya, media hanyalah alat bantu yang digunakan guru untuk menerangkan pelajaran. Alat bantu pertama yang digunakan adalah alat bantu visual, yakni berupa berupa sarana yang dapat memberikan pengalaman visual kepada siswa, antara lain untuk mendorong motivasi belajar, memperjelas dan mempermudah konsep yang abstrak dan mempertinggi daya serap belajar.

Manfaat dari media pembelajaran dalam proses belajar adalah untuk menyampaikan pesan supaya tercapai tujuan yang diharapkan. Media pembelajaran tidak hanya menjadi alat bantu guru, melainkan sebagai alat pembawa materi atau pesan dari guru dalam memberikan materi pelajaran kepada anak.

Fungsi media dalam kegiatan pembelajaran merupakan bagian yang sangat menentukan efektivitas dan efisiensi pencapaian tujuan pembelajaran. Secara keseluruhan menurut McKnow yang dikutip oleh Sihkabuden (2005:19) menyatakan bahwa fungsi media terdiri dari :

a. Mengubah titik berat pendidikan formal, yang artinya dengan media pembelajaran yang sebelumnya abstrak menjadi konkret, pembelajaran yang sebelumnya teoritis menjadi fungsional praktis

b. Membangkitkan motivasi belajar

c. Memperjelas penyajian pesan dan informasi

d. Memberikan stimulasi belajar atau keinginan untuk mencari tahu. 
Menurut Gagne dan Briggs (1975) media pembelajaran meliputi alat yang secara fisik digunakan untuk menyampaikan isi materi pengajaran yang terdiri dari buku, tape recorder, kaset, video camera, video recorder, film, slide (gambar), foto, gambar, grafik, televisi dan komputer. Idealnya pembelajaran bahasa Inggris pada anak usia dini menggunakan metode yang menyenangkan dengan media yang memiliki fitur audio, visual dan interaktif. Adapun media pembelajaran dapat di kelompokkan menjadi 3 bagian antara lain:

a. Media visual

Adalah media yang menyampaikan pesan melalui penglihatan peserta didik/media yang hanya dapat dilihat, seperti:

- Gambar diam (gambar manusia, binatang dan sebagainya)

- Media grafis adalah media pandang dua dimensi (gambar dan tulisan) menggunakan kata-kata, angka serta bentuk simbol (lambang)

- Media model adalah media tiga dimensi, tiruan dari beberapa objek nyata seperti objek terlalu besar, terlalu jauh, terlalu kecil, terlalu mahal dan yang jarang ditemukan atau terlalu rumit dibawa ke dalam kelas.

- Media realita merupakan alat bantu visual dalam pembelajaran yang berfungsi memberikan pengalaman langsung (direct experience) kepada anak, seperti mata uang, tumbuhan, binatang yang tidak berbahaya.

b. Media audio

Media audio adalah media yang mengandung pesan dalam bentuk auditif (hanya dapat didengar) yang dapat merangsang pikiran, perasaan, perhatian dan kemauan anak untuk memahami/ mempelajari isi tema, seperti kaset suara/radio.

c. Media audiovisual

Media ini bisa disebut media pandang dengar, dengan menggunakan media ini maka penyajian isi tema kepada anak akan semakin lengkap dan optimal dan peran guru beralih menjadi fasilitator belajar saja. contoh media audiovisual adalah televisi/ video pendidikan dan sebagainya.

6. Sumber Belajar

Sumber belajar adalah sumber pengetahuan yang memiliki beberapa macam pengertian, yaitu sumber belajar di tinjau dalam 
pengertian yang sempit sampai pada pengertian yang luas.

Sumber belajar dalam cakupan yang sempit maka sumber belajar hanya tercakup pada buku-buku atau bahan-bahan tercetak lainnya seperti majalah, buletin dan sebagainya. Dan dapat diartikan sebagai semua sarana pengajaran yang dapat menyajikan pesan yang dapat di dengar (secara auditif) maupun yang dapat di lihat (secara visual) saja. Misalnya radio, televisi dan perangkat keras (hardware).

Diantara sumber belajar yang menguntungkan bagi anak-anak adalah lagu, cerita dan permainan juga crafting (keterampilan).

a. Lagu

Pengenalan dan penerapan unsur bahasa pada kegiatan pembelajaran, siswa menerima materi pelajaran yang terkandung dalam lagu dari guru sebagai tahap awal dari proses belajar dan pembelajaran. Pemahaman yang dimaksudkan yaitu siswa mampu memahami konsep unsur-unsur bahasa melalui proses pengenalan lagu. Sedangkan maksud penerapan adalah siswa mampu menerapkan materi ajaran yang telah diterima melalui proses pengenalan lagu dalam berkomunikasi.

Lagu yang digunakan sebagai sumber belajar bahasa Inggris pada pendidikan anak usia dini hendaknya mempertimbangkan: pertama, lagu sudah dikenal atau disukai oleh anak. Kedua, lagu harus berisi materi yang akan diajarkan, baik keterampilan bahasa maupun unsur bahasanya. Ketiga, lagu harus memiliki sifat dan karakter yang mengandung pencapaian tujuan pembelajaran. Keempat, lagu harus memiliki tingkat kesulitan yang sesuai dengan kemampuan siswa. Kelima, lagu harus berisi pesan atau nilai yang sesuai dengan tingkat usia dan kematangan siswa. Kesalahan pemilihan lagu akan berakibat pada pembentukan kepribadian yang salah.

b. Cerita

Menurut Wright (1995:3), cerita yang di dalamnya termuat sejumlah banyak kata, menyajikan pengalaman bahasa yang kaya. Selain itu cerita juga mampu memotivasi, kaya unsur pengalaman bahasa dan tidak mahal. Wright juga membedakan istilah telling story dengan reading story. Dengan telling story, siswa akan merasakan guru memberikan sesuatu yang sangat "personal".

c. Permainan

Toth (1995 dalam Mei and Yu-Jung, 2000) mendefinisikan permainan sebagai aktivitas yang memiliki aturan, tujuan dan di 
dalamnya terkandung unsur rasa senang. Lebih jauh Toth membagi permainan ke dalam competitive game dan cooperative game. Dalam suatu permainan kompetisi, siswa berlomba untuk menjadi yang pertama mencapai hasil atau tujuan. Sedangkan dalam permainan kerja sama siswa bekerja sama untuk meraih tujuan bersama. Fokus dari permainan bukan pada ketepatan bahasa tapi pada komunikasi. Menurut Brewster dkk (2002:172) menuliskan bahwa dengan permainan siswa bisa belajar bahasa dalam suasana yang rileks dan menyenangkan. Dengan demikian, permainan bisa membantu guru membuat siswa tertarik dan terlibat dalam proses belajar mengajar.

d. Crafting

Crafting melatih siswa mengembangkan otak juga otot motoriknya. Menurut Ellis dan Brewter, communicative approach mengacu pada activity-based dan seringnya melipatkan penggunaan 3 jenis aktivitas seperti: pertama, adalah problem-solving activities misalnya identifying, matching, sequencing, prioritizing a classifying, kedua adalah interactive activities, seperti making survey, or carrying out interview dan ketiga creative activities, such as making mask, birthday cards, dan sebagainya.

7. Proses Pembelajaran

Berkaitan dengan proses belajar mengajar dan metode yang relevan dengan anak usia dini dalam belajar bahasa Inggris, Moeslichatoen, (1999) mengajukan beberapa metode yang layak, relevan dan menganut konsep pembelajaran yang kreatif, aktif, dan menyenangkan. Metode-metode pembelajaran bahasa Inggris untuk anak usia dini yang bisa digunakan misalnya, 1) bermain dan bernyanyi, 2) bercakap-cakap, 3) bercerita/story telling, 4) demonstrasi, 5) karya wisata, 6) proyek, dan 7) pemberian tugas.

Sejalan dengan metode/strategi yang layak dan relevan untuk digunakan dalam proses pembelajaran bahasa Inggris bagi anak usia dini, http://www.teyl.com/4/1/2010 menyatakan bahwa metode/cara/ instrumen yang relevan dan kontekstual serta mampu menciptakan suasana kreatif, aktif, dan menyenangkan bagi anak usia dini dalam belajar bahasa Inggris adalah 1) using gestures one flash cards, 2) using games, 3) using music, songs, and chants, 4) using dance and movement, 5) using dialogue, drama, and poetry, 6) using stories and story telling, 7) using crafts and activities, 8) project work, 9) using technology in the classroom, and 10) pair and group work. 
Sejalan dengan hal tersebut, Shin, (2006) menambahkan bahwa ada beberapa aktivitas/kegiatan pendukung dalam proses pembelajaran bahasa Inggris bagi anak usia dini yang efektif dan menyenangkan bagi siswa. Kemudian, hal-hal yang perlu diperhatikan dalam melakukan kegiatan pembelajaran bahasa Inggris untuk anak usia dini agar pembelajaran tersebut dapat mencapai tujuan seperti yang diharapkan:1) melengkapi aktivitas pembelajaran dengan media visual, realitas dan gerakan-gerakan serta kombinasi antara bahasa lisan dengan "bahasa tubuh" atau "demonstrasi", misalnya, seorang guru mau memberikan kosakata tentang binatang. Maka guru tersebut harus menunjukkan gambar atau boneka yang berbentuk binatang. Dengan itu akan lebih cepat ditangkap dan dipahami oleh anak. Karena selain mendengar, visual anak bisa melihat langsung secara empiris. Metode seperti ini jika dikaitkan dengan konsep pendidikan modern, dapat dikatakan sebagai salah satu aplikasi konsep CTL (Contextual Teaching and Learning), 2) melibatkan anak-anak di dalam pembuatan media visual atau realita, 3) berpindah dari aktivitas yang satu ke aktivitas lainnya dengan cepat, 4) membangun rutinitas di dalam kelas dengan menggunakan bahasa Inggris, 5) menggunakan bahasa ibu apabila diperlukan, 6) mengajar berdasarkan tema dan menstimulasi imajinasi dan kreativitas anakanak, 7) menggunakan cerita dan konteks yang sudah dikenal oleh anakanak, 8) mengundang masyarakat sekitar yang bisa berbahasa Inggris untuk bercerita di dalam kelas, 9) berkolaborasi dengan guru lainnya di sekolah, dan 10) berkomunikasi dengan guru atau pengajar untuk anak usia dini lainnya di luar sekolah. (Shin, 2006)

8. Lingkungan

Lingkungan merupakan kesatuan ruang dengan semua benda dan keadaan makhluk hidup termasuk di dalamnya manusia dan perilakunya serta makhluk hidup lainnya. Atau lingkungan adalah segala sesuatu yang ada di sekitar/di sekeliling. Lingkungan terdiri dari unsurunsur biotik (makhluk hidup) abiotik (benda mati) dan budaya manusia.

Lingkungan sebagai sumber belajar dapat diartikan segala sesuatu yang ada di sekitar/di sekeliling anak (makhluk hidup, benda mati, dan budaya manusia) yang dapat dimanfaatkan untuk menunjang kegiatan belajar dan pembelajaran secara lebih optimal.

Pemanfaatan lingkungan sebagai sumber belajar di PAUD mengarahkan anak pada peristiwa dan keadaan yang sebenarnya, keadaan alami sehingga lebih nyata, lebih aktual dan kebenarannya lebih 
dipertanggung jawabkan, manfaat nyata yang dapat diperoleh dengan penggunaan lingkungan diantaranya adalah:

a. Menjadikan berbagai hal yang dapat dipelajari oleh anak-anak.

b. Memungkinkan terjadinya proses belajar yang lebih bermakna (meaningful learning)

c. Memungkinkan terjadinya proses pembentukan kepribadian anak.

d. Kegiatan belajar akan lebih menarik bagi anak.

e. Menumbuhkan aktivitas belajar anak (learning activities).

Jenis-jenis lingkungan yang dapat dimanfaatkan untuk mengoptimalkan kegiatan pembelajaran di PAUD terdiri atas lingkungan alam/fisik dan lingkungan sosial. Lingkungan alam/fisik adalah segala sesuatu yang alamiah dan sifatnya relatif menetap, seperti air, tanah, batubatuan, tumbuhan, hewan, sungai,iklim, suhu udara. Lingkungan sosial berkenaan dengan interaksi anak dalam kehidupan bermasyarakat serta dapat digunakan untuk mempelajari ilmu-ilmu sosial dan kemanusiaan.

\section{PENUTUP}

Dari uraian singkat di atas, dapat disimpulkan bahwa sesuai dengan karakteristik anak usia dini, desain pembelajaran bahasa Inggris hendaknya diarahkan pada kegiatan yang bersifat menghibur, rekreatif, dan mendidik agar motivasi yang mereka miliki pada saat ini akan dipertahankan atau bahkan ditingkatkan lagi di masa yang akan datang sehingga pembelajaran bahasa Inggris akan terus berlangsung sepanjang hidup mereka. Substansi kebahasaan pembelajaran Inggris pada pendidikan anak usia dini ditinjau dari dua aspek utama yaitu keterampilan berbahasa (language skills) dan komponen kebahasaan (language components). 
Ida Vera Sophya

\section{REFERENSI}

Berk L. Edan A Winsler. 1995. Scaffolding Children Learning; Vygotsky and Early Childhood education. Washington DC:NAEYC

Brewster, J. Ellis G., \& Girard, D. 2002. The Primary English Teacher's Guide. England: Pearson plc

Departemen Pendidikan Nasional. 2004. Acuan Menu Pembelajaran Pada Kelompok Bermain. Jakarta:Direktorat Pendidikan Anak Usia Dini

Gagne, Robert, M. Leslie J. Briggs. 1979. Principles of Instructional Design, Second Edition. New York:Holt and Winston

Kostelknik, Marjorie J.(editor). 1991. Teaching Young Children Using THEMES. Glenview, Illinois : Good Year Books

Mei, Yin Yong \& Yu-Jing, J. 2000. From Using Games in an EFL Class for Children. Daejin University ELT Research Paper. Fall

Wright, A. 1995. Story Telling With Children. Oxford:OUP

Wright, A. Betteridge, D \& Buckby, M. 1984. From Games for Language Learning. Cambridge: Cambridge University Press 